\title{
DA REPULSA AO GOSTO DA MINA: UMA ANÁLISE SOBRE A CONSTRUÇÃO DO HEROÍSMO DOS TRABALHADORES ${ }^{1}$
}

Marta Cioccari ${ }^{2}$

\section{Introdução}

Meu interesse pelo que, posteriormente, levou-me ao tema desta pesquisa sobre a construção do heroísmo e da honra entre mineiros de carvão - foi despertado ainda em minhas primeiras visitas a Minas do Leão (RS), entre meados e o final da década de 1990, quando eu exercia a profissão de jornalista, muito antes de pensar em tornar-me antropóloga. Naquele período, vivenciei a vertigem de descer às minas de subsolo e travei os primeiros contatos com esses trabalhadores, alguns dos quais se converteriam em informantes nas etnografias que faria anos mais tarde. Numa ocasião, Leo, velho mineiro de carvão, ao me explicar sua ligação com a mina de subsolo, tecida ao longo de 35 anos dos seus mais de 70 anos de vida, me disse: "O carvão é como o mar, apaixona a gente". O seu relato continha não apenas a magia dos subterrâneos, mas também a dimensão das tragédias a que assistiu e a contabilidade dos companheiros que perdeu. Evidenciava que o engajamento no mundo da mina - como aquele do mar continha seus riscos, sortilégios e armadilhas, enfrentados cotidianamente pelos trabalhadores a partir de sua habilidade, de sua força ou de sua coragem. Essas imagens retornariam nas falas de outros interlocutores e passariam a povoar minhas reflexões, retomadas no mestrado (2002-2004) e no doutorado (2005-2010).

Noutra ocasião, escutei Zecão, mineiro ainda hoje em atividade na Companhia Riograndense de Mineração (CRM) refletir sobre o seu ofício: "Pra mim, o mineiro de subsolo é um herói”, definiu, referindo-se à trajetória do pai e do avô, que haviam trabalhado no Cadem e na Copelmi (companhias de mineração privadas), e de quem havia herdado a profissão. Alguns anos depois, este mesmo operário referiu-se ao filme Germinal, uma adaptação cinematográfica da obra de Émile Zola, ao qual já havia assistido por várias vezes: “Germinal é a história que meu pai contava, a história que eles viviam, entendeu?" Zecão se referia ao trabalho de crianças nas minas gaúchas e ao

\footnotetext{
${ }^{1}$ Este artigo é uma versão modificada e parcial de um capítulo da minha tese de doutorado, defendida no PPGAS-MN-UFRJ, em 2010. Agradeço a leitura atenta e as observações feitas na época pelos professores - e hoje colegas - que compuseram a minha banca: José Sergio Leite Lopes, Moacir Palmeira, Luiz Fernando Dias Duarte, Cornelia Eckert e Elina Pessanha. À Cornelia, devo o fato de ter inspirado diretamente minhas pesquisas sobre heroísmo quando foi minha orientadora de mestrado. Sou grata ainda às agências Capes e CNPq, que possibilitaram minha dedicação a esta pesquisa.

${ }^{2}$ Universidade Federal do Rio de Janeiro, Brasil.
} 
uso de cavalos para a retirada do mineral. O comentário estabelecia uma estreita conexão entre a transmissão de valores familiares e a fonte literária que havia despertado meu próprio interesse por aquele universo. ${ }^{3}$ Desta forma, as referências feitas por meus interlocutores, tanto acerca do heroísmo mineiro, da comparação da mina com o mar, como na identificação da sua trajetória familiar com o mundo da literatura, acabaram por delinear um trajeto de pesquisa, do qual este artigo esboça apenas uma parcela.

Neste artigo, em particular, examino a forma pela qual a imagem de heroísmo ou a "grande honra" da profissão - visível ainda entre os operários franceses, como pude verificar durante trabalho de campo realizado na Lorena em fevereiro e junho de 2008 foi alimentada pela literatura, a partir das obras de Victor Hugo (1866) e Émile Zola (1881), mas também ganhou corpo com as campanhas estatais, com o apoio de sindicatos, visando tornar o mineiro "o primeiro operário" do país e convertê-lo num modelo moderno do proletariado (Desbois, Jeanneau e Mattéi, 1986). As homenagens, as medalhas e placas concedidas ainda recentemente pelo Estado e pela companhia de mineração aos trabalhadores, enaltecendo a "honra do trabalho", foram os últimos vestígios de uma política que, no passado, teve como propósito estimular a produção carbonífera na crise gerada pela Segunda Guerra Mundial. Mas a construção deste heroísmo dos mineiros, numa imagem que atravessa várias culturas, começou bem antes, como procuro evidenciar neste trabalho.

\section{Um combate travado nos subterrâneos}

Se as grandes imagens ligando o mar à mina, o "amor" ou a "paixão" pelo trabalho no subsolo estão presentes no imaginário das classes populares, pode-se dizer que tal presença integra uma circularidade (Bakhtin, 1987) em torno de ideias que contribuíram para a construção de um modelo heroico na vida desses trabalhadores e que ressurgem de tempos em tempos, alimentadas pela literatura, pelo cinema, pelas mídias e pelos estudos técnicos e acadêmicos. Investigações de historiadores, antropólogos, sociólogos e cientistas políticos conduzidas sobre os trabalhadores das minas já abordaram aspectos de sua identidade heroica. ${ }^{4}$ Lucas (1981), por exemplo,

\footnotetext{
${ }^{3}$ Meu interesse pelo mundo da mina foi despertado justamente pela leitura de Germinal, de Zola, aos 14 anos e acompanhou-me pelas décadas seguintes.

${ }^{4}$ Destaco, entre as pesquisas feitas no Exterior, as obras de R.Trempé (1971), Ph. Lucas (1981), E. Desbois, Y. Jeanneau e B. Mattéi (1986), M. Lazar (1985, 1990), O. Schwartz (2002), G. Noiriel (2002),
} 
ressaltava que os mineiros se lançam a um combate singular, « uma espécie de corpo-acorpo com o Elemento » e sua fraternidade, sua solidariedade, ganha corpo na especificidade deste combate. Estudos realizados a partir dos anos 1980 no Brasil indicavam que o mineiro de subsolo trabalha "vendo a morte nos olhos dos outros", como mencionou Grossi (1981), ou num "cotidiano com o cheiro da morte", segundo um operário ouvido por Eckert (1985). Tal dimensão de uma heroicidade relacionada ao perigo encontra seu correspondente em outros segmentos de trabalhadores. Assim como “ir ao mar” para pescadores de Jurujuba (RJ), pesquisados por Duarte (1987: 174), significa "embrenhar-se no limiar", "enfrentar o desconhecido", para os mineiros de Minas do Leão (RS), "baixar à mina" reveste-se de sentido similar. Nas entranhas da terra ou em alto mar ingressa-se numa zona de incerteza.

Em sua longa tradição, iniciada na Europa por volta do século XVI, mas intensificada nos séculos XVIII e XIX durante a chamada Revolução Industrial, a atividade de mineração subterrânea foi construída sob o signo do perigo e da insalubridade. Essas características contribuíram diretamente para uma imagem heroica dos trabalhadores. Uma análise da trajetória deste segmento operário na Europa - mais especificamente o caso francês - nos ajuda a compreender o fenômeno que encontra eco nas representações de trabalhadores gaúchos. Na observação de traços da longa história da mineração subterrânea de carvão na Europa - onde o mineral era chamado de o "pão da indústria", com importância decisiva entre 1850 e 1950 - podem-se vislumbrar mais nitidamente aspectos que se entrevê na jovem tradição carbonífera brasileira.

A indústria brasileira de carvão se desenvolveu na esteira do exemplo europeu, de forma que as primeiras vilas-mineiras na região carbonífera do Baixo Jacuí, no Rio Grande do Sul, onde está situada a cidade de Minas do Leão - local em que conduzi minha etnografia -, se constituíram entre o final do século XIX e meados do século XX. Durante um século, a exploração de carvão na região contou com a experiência de imigrantes europeus (sobretudo ingleses, alemães, espanhóis, poloneses, ucranianos, iugoslavos, russos, etc.), havendo o intercâmbio de técnicas de extração, mas também de formas de organização e de resistência - assim como de um imaginário dos

C. Eckert (1991, 1993), J. Michel (1993), J. Ponty (1995, 2008), C. Roth (2002), D. Cooper-Richet (2002), sobre mineiros na França; D. Lancien (1981), H. Beynon (1996, 1999), sobre os trabalhadores nas minas na Grã-Bretanha; R. Clyne (1999), sobre uma área mineira no Colorado, nos EUA; A. Kassapi (2001), sobre mina da Grécia do Norte; B. Moore Jr. (1987), sobre mineiros de carvão na Alemanha; J. Nash (1979), J. Nash \& J. Rojas (1976) sobre mineiros de estanho bolivianos. Sobre as pesquisas no Brasil, são referências obrigatórias os trabalhos de C. Eckert (1985), Y. Grossi (1981), T. Volpato (1982), M. C. Minayo (1986), C. E. Silva (2007), entre outros. 
subterrâneos. Se tomo aqui o caso francês como referência para a análise do surgimento da "grande honra" é devido à abundância de estudos relativos ao tema naquele contexto e, também, à minha própria experiência de pesquisa em Creutzwald, na Lorena francesa.

É importante se considerar que a identidade coletiva do mineiro de subsolo pretende-se universal, atravessando fronteiras e tempos históricos. Tanto em minha pesquisa no Brasil como na França, notei entre meus interlocutores esse sentimento de proximidade em relação a mineiros de outros tempos e/ou de diferentes países, mais do que a outras categorias operárias próximas do ponto de vista temporal ou geográfico. $\mathrm{Na}$ França, os ex-operários me perguntavam sobre a vida e sobre as condições de trabalho de seus "colegas" brasileiros; em Minas do Leão (RS), alguns ex-mineiros assistiram atentos às imagens do subsolo da mina francesa que lhes mostrei e queriam saber tanto da qualidade do mineral como de minhas impressões sobre os trabalhadores de lá. Certa vez, quando assistíamos a um DVD sobre o último dia de trabalho dos operários franceses ${ }^{5}$ na mina La Houve, Hermes, ex-mineiro de Leão I, na cidade gaúcha de Minas do Leão, reagia assim, com os olhos brilhando: "Meu Deus, que saudade! Meu Deus, que saudade!” A mina francesa que via na tela tinha uma relação de continuidade com a mina na qual ele havia trabalhado e que também havia sido desativada. Ao anoitecer, enquanto tomávamos café, Hermes cantou para mim e sua esposa versos de uma canção em francês que aprendera na escola, cujo significado não suspeitava, mas que ficaram gravados desde aqueles poucos anos de escolarização de sua infância. Parece-me que o que une esses trabalhadores é o sentimento de pertencer a um "nós, os mineiros". Esta cumplicidade tácita - da qual eu mesma participava, com uma pesquisa atravessando os dois universos - foi evocada na dedicatória do livro Nous les mineurs ${ }^{6}$, que recebi de presente de um ex-mineiro e sindicalista francês.

As primeiras imagens sobre o "heroísmo mineiro" na França surgem com Simonin (1982 [1867]), antigo engenheiro das minas do Loire, tornado o principal ideólogo das companhias carboníferas, que escreveu uma obra de vulgarização, La vie souterraine: les mines et les mineurs, cuja inspiração menciona ter partido do romance de Victor Hugo, Os trabalhadores do mar (1971 [1866]), publicado um ano antes. A conexão entre o mar e a mina aparecia explicitamente na obra de Simonin, na qual ele destacava a aproximação dos dois universos, citando a (então) recente obra de Hugo:

\footnotetext{
${ }^{5}$ Trata-se do documentário Poste du matin à La Houve, 2004.

${ }^{6}$ Obra de J.C. Poitou, editada em 1983 pela Federação Nacional dos Trabalhadores de Subsolo da CGT. A dedicatória dizia: "Com todo o meu reconhecimento pelo interesse que portas à nossa profissão".
} 
"Aquilo que ele [Hugo] chama tão adequadamente de obstáculo, a ananke dos elementos, se dirige também contra o mineiro. Como o marinheiro, ele é o soldado do abismo, e contra ambos obstina-se fatalmente a natureza" (Simonin, 1867: I). ${ }^{7}$ Esta representação do trabalho na mineração subterrânea como "um combate" e do mineiro como "um soldado" figurará durante muito tempo nos discursos políticos e perdurará na fala dos operários. Por parte das empresas carboníferas, a imagem de "herói do trabalho" será evocada especialmente após as tragédias nas minas, como forma de fazer frente a greves e rebeliões e de chamar os mineiros ao cumprimento de seu "dever".

Na comunidade mineira de Anzin, no Norte da França, por exemplo, entre 1909 e 1911, cerca de $20 \%$ dos trabalhadores tiveram um acidente de trabalho, dos quais um sobre dez ficaria permanentemente incapacitado (Michel, 1993: 36). Depois de uma tragédia, Anzin foi palco de uma greve de mineiros que durou 56 dias e atraiu as atenções do escritor Émile Zola. Em fevereiro de 1884, Zola entrou na "gaiola" para descer os 675 metros de profundidade no poço Renard, em Denain, enfrentando o sentimento aterrador de um mergulho nos "infernos", em meio à escuridão e à umidade daqueles subterrâneos: uma espécie de chuva lhe caía sobre os ombros à medida que o elevador descia no abismo. ${ }^{9}$ Foi quando o escritor conheceu de perto o mundo dos mineiros de carvão, cuja atmosfera transportaria para o romance Germinal, publicado em 1885, no qual retratava o cotidiano penoso, a revolta e a luta desses trabalhadores contra o capital, a companhia carbonífera. A denúncia da exploração e do sofrimento a que os mineiros eram submetidos aparece então na literatura naturalista com uma ênfase que jamais tivera, sendo depois as observações do escritor comparadas a uma "verdadeira etnografia". ${ }^{10}$ Sua obra será uma das principais contribuições para o imaginário coletivo sobre a vida dos trabalhadores no subsolo - no qual os próprios operários iriam se apoiar para falar de si - e não apenas os franceses ${ }^{11}$, como se viu na referência feita pelo mineiro gaúcho.

\footnotetext{
${ }^{7}$ Uma análise sobre a categoria da natureza nesta obra de Hugo está em Cioccari (2010a, 2010b).

${ }^{8}$ Termo utilizado para se referir às minas que aparece num poema de Louis Aragon, em 1940: “Enfer-lesmines". Ver Lazar, 1990: 1092; Cooper-Richet, 2002: 58.

${ }^{9}$ Zola descreve essa descida às galerias da mina em seu caderno de notas. Este material foi organizado por Henri Mitterand e publicado no capítulo "Dans le corons", do livro Carnets d'enquête: une ethnographie inédite de la France (Zola; Mitterand, 1987).

${ }^{10}$ Zola realizou um estudo minucioso da sociedade francesa para escrever a saga dos Rougon-Macquart, onde se insere o livro Germinal. Após vinte anos de observações, o escritor reuniu as principais características da etnografia: o trabalho de campo, a observação de fenômenos particulares a grupos restritos, a análise e observação dos fenômenos observados para elaborar documentos descritivos e sínteses (Zola; Mitterand, 1987: 13).

${ }^{11}$ Cooper-Richet (2002: 7) considera que, graças ao Germinal, a mina e os mineiros entraram por longo
} 
Antes de Zola, outros escritores haviam tomado a mina por tema, como Elie Berthet, que publicou em 1866 Les houilleurs de Polignies. O jovem Zola, que trabalhava na editora que lançou o livro, foi um dos primeiros a ler o romance, tendo escrito um comentário para um boletim. ${ }^{12}$ Posteriormente, a vida dos mineiros passaria a inspirar novas obras de ficção, além de biografias e autobiografias operárias. Elas iriam se mesclar, aderindo ou se contrapondo, às imagens propaladas pelas próprias companhias sobre o "heroísmo mineiro" e cuja influência parece atravessar um pouco todas as culturas. ${ }^{13}$ Os mineiros - ou, naquele contexto, os gueules noires - se tornariam figuras míticas, capazes de despertar uma mescla de compaixão e de admiração, reputados por sua coragem física, sua resistência, sua solidariedade profissional e o orgulho por seu ofício (Cooper-Richet, 2002: 7). O mundo subterrâneo suscitava medo e respeito, repulsa e fascinação. A imagem do mineiro, em boa parte forjada pela grande imprensa do final do século XIX, ganhava contornos dramáticos: o trabalhador tornavase conhecido pelos riscos que enfrentava ou pelas lutas que conduzia. Perigo e solidariedade tornaram-se palavras-chaves para se falar do mineiro. Como outras profissões viris que empreendem grande esforço físico - por exemplo, os marinheiros - a profissão de mineiro passou a ser vista como geradora de comportamentos coletivos, com uma identidade vinculada ao trabalho. Foi ganhando força a noção de uma adaptação hereditária, com a transmissão do ofício de pai para filho. Na imagem da grande corporação "como uma família", nutria-se a idéia do "amor pelo trabalho" e do devotamento aos companheiros (Michel, 1993: 98-100).

Noiriel (2002: 110) destacava a afirmação de Trempé de que “a repugnância pelo trabalho subterrâneo" havia se transformado em verdadeira repulsa no começo do século XX, na França, de forma que era difícil de recrutar operários para a mina e mais difícil ainda mantê-los. Neste contexto, as políticas paternalistas adotadas pelas companhias carboníferas tinham, justamente, o intento de vencer tal repulsa. Uma das formas foi a midiatização de imagens em torno do mineiro corajoso, amante de seu ofício e disposto a todos os sacrifícios. Um mito fundador das imagens heroicas pode estar situado em 1812, durante uma catástrofe com dezenas de mortos numa mina na Bélgica, quando um mineiro, Goffin, após ter salvado da morte 60 companheiros, foi condecorado por Napoleão Bonaparte com a "Legião de Honra". Por outro lado, uma

\footnotetext{
tempo e com uma forte carga emocional no patrimônio cultural dos franceses.

${ }_{13}^{12}$ A este propósito, ver Cooper-Richet, 2002: 176-177.

13 Mineiros de ferro, chamados de "gueules jaunes" para se diferenciarem dos "gueules noires", lamentavam não terem tido o seu Zola, que retratasse suas peculiaridades. Ver Nezosi, 2008.
} 
explicação para a insistência em fazer do mineiro um mito poderia ser a necessidade de combater sua resistência a se tornar este herói pronto ao sacrifício. Ao contrário do que sugere a propaganda, a idéia do heroísmo e do amor ao trabalho não parece ser inata (Mattéi, 1986: 89-91). Boa parte dos mineiros não tinha vontade de arriscar a sua vida no subsolo - como se percebe nos registros sobre o medo e a resistência à mina, sob a forma de absenteísmo e evasões, apontados na literatura e nas entrevistas realizadas por mim em Creutzwald.

Foi necessário então um longo trabalho de convencimento para que o perfil do operário correspondesse ao mito, ainda assim com suas dissidências. Ao falarem deles mesmos os mineiros não usavam termos muito diferentes dos usados pelos patrões. No caso francês, ainda que os sindicatos denunciassem os objetivos patronais, retomavam à identidade idealizada. Os discursos do primeiro líder do sindicalismo mineiro francês, Michel Rondet, por exemplo, exprimem esta dualidade: “O mineiro não é um operário comum, ele é, numa palavra, um soldado que combate constantemente para encher os cofres de nossos capitalistas". ${ }^{14}$ Seu discurso associava a imagem do soldado, tomada de empréstimo a Simonin, à análise socioeconômica inspirada no socialismo e no sindicalismo nascente. Rondet dizia que o mineiro "tem por céu algumas centenas de metros de rochas sobre a cabeça, ameaçando-o continuamente, por sol, uma lâmpada (...)". Para ele, o mineiro seria um trabalhador com uma espada de Dâmocles suspensa sobre a cabeça (Michel, 1993: 102). Após sua morte, o próprio Rondet foi convertido em herói: sua estátua figura numa praça de La Ricamarie, na região do Loire, na França. Como tradução da "grande honra", em diferentes lugares do mundo encontram-se imagens esculpidas de mineiros sobressaindo na paisagem das zonas carboníferas: a figura do ex-mineiro soviético Alexei Stakhanov, por exemplo, está em Donbass, na Ucrânia, e a de um mineiro desconhecido, em Arroio dos Ratos, no sul do Brasil.

\section{A idealização do trabalhador pelos comunistas}

Se a identidade heroica conferida ao mineiro de carvão deve seu tributo a Zola foi, em grande parte, renovada pelo Partido Comunista Francês e pelo movimento comunista internacional, que fizeram destes trabalhadores uma espécie de "farol" do proletariado (Cooper-Richet, 2002: 9). Os estudos de Marc Lazar (1985, 1990) mostram que o PCF investiu de tal forma na figura do trabalhador das minas e na defesa do

\footnotetext{
${ }^{14}$ Apud. Mattéi, 1986: 91-92.
} 
carvão como fonte energética que, na França, estes operários acabaram por se tornar paradigmas da própria identidade comunista. Durante e após a Segunda Guerra Mundial, os mineiros encarnaram a identidade comunista operária, nacional e revolucionária, relação que, naquele contexto, ainda mantém seus resquícios. $\mathrm{O}$ interesse pelos mineiros se manifestou a partir dos anos 1930. Em 1937, foi publicada Fils du peuple, a autobiografia do secretário-geral do partido, Maurice Thorez, filho e neto de mineiros do Norte da França, ele mesmo um ex-aprendiz da mina de subsolo. ${ }^{15}$ As ligações com o mundo da mina compõem um dos principais aspectos da legitimidade e da grande popularidade de Thorez. Entre o fim dos anos 1940 e início dos anos 1950, a mina e os mineiros receberam atenções da intelectualidade e dos artistas. A profissão, que gozava de imenso prestígio no partido, desfrutava de importância econômica. Em 1946, o carvão gerava $80 \%$ da energia nacional. As companhias carboníferas empregavam 330 mil trabalhadores - número que baixaria para 215 mil em 1955, em decorrência da modernização e da mecanização. Além da busca de uma base política, os comunistas eram atraídos pela forte ligação dos mineiros com seu ambiente de trabalho. ${ }^{16}$

$\mathrm{O}$ mineiro visto pelos comunistas não tinha, porém, os traços resignados e embrutecidos que se vislumbram em certas páginas de Germinal, mas, ao contrário, foi erigido em modelo de moral e de virtude, "investido de uma missão prometéica". ${ }^{17}$ Como ressalta Lazar (1985, 1990), o próprio mundo da mina, símbolo do inferno capitalista, por efeito dialético tornava-se o lugar privilegiado do movimento operário. A tese que sustentava a valorização do trabalho manual, o amor pelo trabalho, o orgulho operário e a comparação do trabalho proletário com a criação artística vinha sendo defendida por Thorez desde 1936: “(...) nossos operários amam suas máquinas como nossos camponeses e nossos artesãos suas ferramentas. Uns e outros amam seu ofício e são tão orgulhosos de sua produção como um grande artista de sua obra-prima". ${ }^{18} \mathrm{O}$ mineiro passava a ser então o protótipo do "novo homem" - a exemplo das esperanças soviéticas -, enfatizando seu caráter solidário, fraternal, disciplinado, corajoso, viril, resoluto, tenaz, generoso e determinado. Os líderes comunistas não se cansavam de exaltar a "beleza" e a "nobreza" do trabalho mineiro, que supunha uma agilidade, uma competência e uma técnica particular (Lazar, 1985: 195). Os mineiros, cuja aura

\footnotetext{
${ }^{15}$ Ver Lazar, 1985: 191; e Lazar, 1990: 1073-1074, 1085.

${ }^{16}$ Neste período, havia também uma forte valorização dos metalúrgicos no PCF. Ver Lazar, 1990.

${ }^{17}$ Lazar, 1985: 197.

${ }^{18}$ Citado por Lazar, 1990: 1077.
} 
revolucionária foi exibida em greves históricas - como a da Resistência, em 1941; contra o imperialismo americano, em 1948; e a destinada a "salvar a honra", em 1963, iniciado o fechamento das minas -, permitiam ao PCF proclamar-se o defensor e o depositário desta herança. ${ }^{19}$

Trempé (1989) e Jean Louis (2000) consideram terem sido três as "batalhas do carvão". A primeira foi a "grande greve patriótica", entre maio e junho de 1941 no Norte da França, que começou como um movimento reivindicativo em Dourges e envolveu 80 mil mineiros. As companhias apelaram para a intervenção de forças alemãs e a área foi ocupada militarmente. Houve centenas de prisões e 270 mineiros foram deportados. A greve, liderada por militantes comunistas clandestinos, ganhou um caráter anti-alemão. Depois, entre 1945 e 1946, uma atualização do heroísmo mineiro ganharia corpo efetivamente na França com as ações do Estado, das empresas e de sindicatos durante a segunda batalha, a da produção, no pós-guerra, quando se forjou mais claramente a identidade social e cultural da "mitologia do mineiro" (Mattéi, 1986: 13). Capturada pela imagem do herói do trabalho, a maioria dos mineiros se engajou no esforço patriótico. A imagem do trabalhador passava a ser, então, a de um "soldado" que vai à frente de produção com a missão de reconstruir o país e assegurar sua independência e liberdade. Neste contexto, promoveu-se uma multiplicação de cerimônias, de homenagens, de entregas de medalhas que pretendiam honorificar os trabalhadores das minas que se engajavam para elevar a produção.

Era um programa organizado pelo Estado, com forte participação do PCF e da CGT, que demandava dos operários extrema dedicação ao seu métier. Slogans publicitários veiculados na imprensa, nas rádios e no cinema, além de cartazes afixados nos muros dos cafés, nas fachadas dos poços e nos estabelecimentos públicos diziam: “Torne-se mineiro, primeiro operário da França", "Mineiro, o destino da França está em tuas mãos!", "Para reconstruir a França, é necessário primeiro o carvão”, “100.000 toneladas de carvão por dia. É isso que a França espera de ti”. Ou ainda: “A pátria está em perigo. Mineiro, você pode salvá-la!”, “As minas de ouro da França são as minas de carvão!", “O carvão é o sangue da França”. A nacionalização das minas, em 1946, prometia criar melhores condições de trabalho, em contrapartida a esse esforço.

A esquerda jogou assim papel essencial nesta heroicização. Thorez, que se tornou ministro de Estado, sustentava que produzir o carvão era "a forma mais elevada

\footnotetext{
${ }^{19}$ Lazar, 1985: 199, 203.
} 
do dever de classe" e era, também, o seu dever como patriotas. As centrais sindicais CGT e CFTC usavam a palavra de ordem: "Trabalhar primeiro, reivindicar depois". A "mitologia do mineiro" consistia num discurso sobre o trabalhador adotado para representá-lo tanto aos seus próprios olhos como aos olhos dos outros, de forma que ele acabasse por interiorizar essa imagem. Os mineiros eram considerados como “destinados", como se vê no discurso de Thorez: "É-se mineiro de pai para filho, são nossos títulos de nobreza". Mas os propalados "amor pelo trabalho" e "honra da profissão" recebiam contestações mesmo entre os dirigentes comunistas, lembrando que o sonho de muitos era o de que os filhos não fossem à mina. ${ }^{20}$ Em décadas mais recentes, a possibilidade de uma escolaridade mais longa para os filhos de operários seria a promessa de outro horizonte, embora esta trouxesse o seu próprio desencanto. ${ }^{21}$

É importante assinalar, nos anos 30, a influência da experiência soviética com o movimento stakhanovista engendrando o reconhecimento social dos mineiros engajados no aumento da produção de carvão. O movimento foi criado em referência ao herói dos mineiros soviéticos, Alexeï Stakhanov, que, em agosto de 1935, bateu o recorde de extração de carvão numa mina em Donetz: em menos de seis horas retirou 102 toneladas de carvão, superando em 14 vezes o padrão de extração. No mês seguinte, novo recorde: 220 toneladas num só turno. Depois da proeza, o mineiro e outros três mil trabalhadores, homens e mulheres, foram homenageados por Stalin numa cerimônia em Moscou. Stakhanov foi matriculado na Academia Industrial de Moscou e seu nome foi utilizado pela propaganda soviética para criar o stakhanovismo, estimulando o esforço revolucionário na superação de metas. $\mathrm{O}$ mineiro chegou a ser capa da revista Time em dezembro de 1935, com uma matéria intitulada "Russia: Heroes of Labor". ${ }^{22}$ Algumas imagens deste período aparecem no documentário La mort du travailleur, produzido em 2005 por Michael Glawogger. ${ }^{23}$ Numa parte, intitulada "Heróis", são exibidos discursos de mineiros soviéticos em meados dos anos 1930, nos quais o melhor operário e a melhor operária de uma mina em Donbass prometem "solenemente" produzir até o final

\footnotetext{
${ }^{20}$ Mattéi , 1986: 25, 33, 39, 41-43.

${ }^{21}$ Como indicaram Beaud \& Pialoux (1999) e Noiriel (2002), as famílias operária na França, desencantadas com a perspectiva de um futuro nas fábricas, orientaram seus filhos em direção a uma escolaridade longa e se decepcionaram também com a eficácia dessa estratégia para melhorar a condição de vida de seus descendentes. A ambiguidade vivida pelas famílias operárias é analisada por Noiriel (2002: 226): “Ao mesmo tempo em que se proclama o 'amor do trabalho', se mobilizam todas as forças familiares reunidas para que os filhos não tenham a mesma vida que se teve". (Tradução minha)

${ }^{22}$ Ver Time, Dec.16, 1935. Disponível em: http://www.time.com/time/covers/0,16641,19351216,00.html.

${ }^{23} \mathrm{O}$ documentário (Alemanha, 2005, 119mn), se debruça sobre a vida de trabalhadores mineiros na Ucrânia, além de outras categorias na Indonésia, Nigéria, Paquistão e China.
} 
do ano 28 mil toneladas de carvão "a mais do que a norma". Nas homenagens prestadas pela população à saída da mina, após o anúncio de um recorde de produção, os "heróis do trabalho" desfilam sorridentes, fortes e vitoriosos, carregando nos ombros as ferramentas, símbolos da profissão. Em meio a flores, aplausos e faixas de "Viva o movimento popular stakhanovista", entoam o hino:

\footnotetext{
Nossa nação engrandece pelo trabalho/ Por toda parte, em nosso vasto país,/ Uma nação de heróis stakhanovistas está em marcha,/ E os mineiros combatem pelo carvão./ (...)

Em tempos de paz como em tempos de guerra,/ Os mineiros amam seu país./ Uma nação de heróis stakhanovistas está em marcha,/ Pronta a enfrentar o inimigo. ${ }^{24}$
}

No documentário, ouvem-se mineiros ucranianos do presente - operários que, com o fechamento da mina estatal ficaram desempregados e decidiram, por conta própria, trabalhar numa mina abandonada - dizendo que não podem se comparar a Stakhanov. Um deles avaliava que as cenas do movimento stakhanovista "não passavam de um espetáculo, de um show". Outro discordava, mencionando que o objetivo era estimular a indústria do carvão. Estavam de acordo, porém, que no seu caso, a motivação era outra: buscavam sobreviver, pois "sem trabalho, morre-se de fome!"

$\mathrm{Na}$ França, a campanha de heroicização do mineiro recebeu a resistência de setores da esquerda que acusaram uma tentativa de docilizar o comportamento operário. Ao contrário de uma narrativa gloriosa, a "grande honra" do mineiro inscreveu-se, portanto, numa mescla de interesses diversos e contraditórios. As reações apareceram sob a forma de revoltas, de greves e de absenteísmo, principalmente nos períodos que se seguiam aos acidentes fatais nas minas, cujas condições de trabalho continuavam precárias. Em 1946, os trabalhadores franceses obtiveram duas conquistas importantes: o estatuto do mineiro e a nacionalização das minas. O estatuto, que passou a vigorar em maio daquele ano pretendia conceder ao mineiro o seu direito à dignidade. Consagraria um regime específico de seguridade social e de aposentadoria vantajosos para a época, reconhecendo a silicose como doença profissional. Os mineiros obtinham o direito à moradia gratuita, sendo colocados no topo da hierarquia operária - seu salário era fixado por relação ao dos metalúrgicos. Os trabalhadores recebiam garantias contra sanções com a criação de comissões paritárias; havia a classificação das categorias e definição de regras de avanço. A nacionalização, com a criação da Charbonnages de France (CDF) agrupando nove companhias, em julho do mesmo ano, foi recebida como

\footnotetext{
${ }^{24}$ Tradução livre a partir da versão em francês.
} 
o fim da exploração. Mas logo veio o desencantamento. Em 1947, após a saída dos ministros comunistas do governo, este recusou aumento salarial à categoria. $\mathrm{O}$ novo patrão tornara-se mais exigente que as antigas companhias (Michel, 1993: 86, 88.)

Seria deflagrada então a terceira batalha do carvão. Os mineiros sentiam que seu esforço durante a guerra não tinha sido recompensado e lançaram mão de greves em 1947 e em 1948. Como reação, o exército ocupou os poços onde ocorreu a mobilização. Uma forte repressão se desencadeou e houve mortes entre os trabalhadores, além de milhares de prisões e de condenações. Muitos artistas e literatos comunistas se engajariam no combate simbólico a favor dos mineiros. ${ }^{25}$ Nos anos seguintes, a companhia efetivava os planos de modernização e de mecanização, com drástica redução dos postos de trabalho: mais de 100 mil vagas seriam cortadas até os anos 1960. Diante dos novos processos de trabalho e da introdução de novos equipamentos, os mineiros descobriam que "não é mais a mesma fadiga" ${ }^{26}$, mas seu trabalho continuava a lhes roubar as forças. Nos anos seguintes, o PCF e a CGT foram gradualmente perdendo espaço no seio da companhia. Nos anos 1960, começaria o fechamento dos poços de extração, em meio a uma crise que se intensificaria nas décadas seguintes (Eckert, 1991; Schwartz, 2002), com protestos violentos de uma categoria que começava a ser extinta. Mobilizando a solidariedade nacional, a histórica greve de 1963 manifestava o sentimento dos mineiros de voltarem a serem "párias", desvalorizados e com salários rebaixados.

Ex-mineiro nascido na Itália, Graziano Balzani, um de meus informantes na Lorena, participou do movimento de 35 dias. Ele recordava que a greve foi dura porque a companhia não aceitava suas reivindicações: "Para que aceitasse, foi necessário que os operários fossem como um bloco de cimento", explicava. Como o pagamento dos salários havia sido suspenso, a certa altura a greve teve que ser interrompida porque, apesar da rede de solidariedade ter mobilizado o país, "havia famílias que não poderiam continuar a viver, pois já não tinham o que comer". O final da greve, com a concessão do governo às suas reivindicações, foi retratado pela imprensa como o dia em que "De Gaulle se dobrou". 27

Filho de operário-camponês da Itália, Graziano Balzani tinha chegado à França em 1956 para trabalhar com um agricultor que produzia açúcar de cana. Depois, foi

\footnotetext{
${ }^{25}$ Em 1949, foi lançado o primeiro romance de André Stil, filho de família operária, Le mot mineur, camarades, e o filme Le point du jour, de Louis Daquin. Ver Lazar, 1985; e Michel, 1993.

${ }^{26}$ Ver Michel, 1993: 90, 91.

${ }^{27}$ Cf. Républicain Lorrain, suplemento especial à edição de 22 de abril de 2004, p.13.
} 
ferroviário e metalúrgico, até ingressar na mina em 1961, na qual se aposentou como chefe de equipe ${ }^{28}$, o nível mais alto permitido a um estrangeiro. Seu caso ilustra bem a situação de milhares de imigrantes que ingressaram nas minas francesas. Deve-se considerar o que escreveu Noiriel (20002) sobre o fato de que, duas décadas antes, até os anos 1940, quase a totalidade dos trabalhadores do subsolo nas minas francesas era de estrangeiros. A eles eram destinadas as tarefas mais duras e perigosas. ${ }^{29}$ A entrada de trabalhadores estrangeiros de origem italiana, polonesa, alemã, iugoslava, entre outras, e, mais recentemente norte-africana, a partir dos anos 1970 e 1980, marcou de maneira significativa o processo de exploração das minas daquele país, as clivagens no interior da categoria e também a distribuição sócio-territorial nas comunidades.

\section{A reação nas autobiografias e romances mineiros}

Uma forma de resistência à mitificação dos trabalhadores das minas surgiu nas autobiografias operárias, como a do mineiro belga Alphonse Bourlard, escritas sob o pseudônimo de Constant Malva. Em Ma nuit au jour le jour, surgida em 1937 e publicada em 1953, ele justificava que queria desmistificar a imagem dos "heróis do subsolo" ${ }^{30}$. Ligado à escola de Henri Poulaille ${ }^{31}$, Malva se perguntava como o mineiro poderia ser um herói consentindo no "destino de escravo". Ex-militante do Partido Comunista, excluído por "trotskismo" em 1927, e a respeito de quem posteriormente pairaram acusações de colaboracionismo, Malva afirmava que os trabalhadores das minas não eram os heróis que a imprensa gostava de pintar depois das catástrofes. "Nós não vamos à galeria por dever, mas por necessidade, porque é preciso ganhar a vida". Negava que os mineiros amassem seu ofício, explicando que eles não escolhiam sua profissão, mas que esta lhes era imposta por certas circunstâncias. Rompia um tabu ao

\footnotetext{
${ }^{28}$ Chef de chantier.

29 A primeira imigração foi de poloneses, instalados principalmente nas minas do Norte. A segunda, de italianos, que se fixaram em torno das minas de ferro na Lorena, com um contingente menor nas minas de carvão. Os norte-africanos, especialmente marroquinos e argelinos, seriam a terceira onda de imigrantes. Para um aprofundamento deste aspecto, ver Noiriel (2002), Ponty (1995, 2008), Eckert (1991) e a publicação Mineurs immigrés.

${ }^{30}$ Outra voz discordante aparece no relato do mineiro Louis Lengrand, que viveu toda a sua vida na mina e que descobre outros horizontes quando é internado com silicose: "Eu não sabia o que era a vida; foi necessário que eu fosse a um hospital para compreender" (citado por Mattéi, 1986: 100). Lengrand diz ainda: "Por todo ouro do mundo, eu não enviaria meu filho à mina. (...) Eu jamais estive na prisão. Quando não se esteve... É como a mina, talvez. É necessário lá ter trabalhado para saber o que é" (citado por Michel, 1993: 104). Um testemunho similar ao de Lengrand me foi dado pelo filho de um mineiro polonês do norte da França, sobre o fato de que seu pai, que engajou na mina todas as suas forças, passou a questionar-se se tinha valido a pena quando se agravaram os sintomas da pneumoconiose.

${ }^{31}$ Escritor anarquista francês (1896-1980) que promovia a literatura proletária.
} 
dizer: "Sim, os mineiros maldizem seu ofício". ${ }^{32}$ Malva, que trabalhou como mineiro de subsolo por vinte anos, morreu de silicose em 1969. Em La nuit dans les yeux (1985), publicada postumamente, ele descreveu o universo sombrio e o medo gerado pela mina.

(...) É quando se está só é que se vê melhor o aspecto sinistro da mina, lugar de desolação e de pavor; onde um silêncio de morte ameaça, onde as sombras como lençóis fúnebres lhes envolvem por todos os lados. Algumas vezes, esse silêncio é rompido pela queda de uma pedra (...). As madeiras quebradas parecem supliciados que se torcem num tormento sem fim; algumas madeiras são fosforescentes: na sombra, se acreditaria ver fantasmas. Meu tio tinha muito medo. Ele passava rápido e sem virar a cabeça nas galerias abandonadas, temendo ver os espectros das vítimas das catástrofes passadas. ${ }^{33}$

Tanto para rechaçar o heroísmo como para exaltá-lo a questão está presente, à maneira de uma referência. Outros mineiros perpetuaram as suas impressões sobre a mina através da escrita de romances: como Alphonse Narcisse, mineiro de subsolo durante 30 anos, que publicou L'ombre de la morte (1954) e Les cités mourantes (1959); e René-Marcelin Attagnant, que começou a trabalhar numa mina aos 12 anos de idade, e escreveu La muse noire (1968). Augustin Viseux, filho e neto de mineiros de Lille, no norte da França, em sua autobiografia, Mineur de fond (1991), narrou, por sua vez, o cotidiano, as vicissitudes e as lutas dos trabalhadores, na longa trajetória na mina iniciada quando ele tinha 15 anos. Passou de função em função até tornar-se engenheiro da mina no fim da carreira, mediante estudos feitos após a jornada diária. No subsolo, enfrentou tragédias e contraiu a silicose. $\mathrm{O}$ ex-mineiro e então engenheiro foi distinguido, em 1987, com a Legião de Honra, homenagem destinada aos "heróis nacionais", instituída por Napoleão Bonaparte em 1802. Ao receber a honraria, segundo os registros em sua autobiografia, ele ouviu: "Você é um exemplo não da bravura vã dos temerários, mas da coragem calma e tranqüila dos heróis". ${ }^{34}$

$\mathrm{O}$ trabalhador das minas teria realmente aderido à imagem heroica que se fez dele? Michel (1993: 102) considerava que o mineiro ama a mina, mas observava nos

\footnotetext{
${ }^{32}$ Citado por Mattéi, 1986: 97.

33 Tradução livre do francês. No original: “(...) C'est quand on est seul qu'on voit mieux l'aspect sinistre de la mine, lieux de désolation et d'épouvante; où un silence de mort plane, où les ténèbres comme des draps funèbres vous enveloppent de toutes parts./Quelquefois ce silence est rompu par la chute d'une pierre ou la plainte d'une bêle qui cède sous la pression du terrain. Les bois brisés semblent des suppliciés qui se tordent en un tourment sans fin; certains de ces bois sont phosphorescents : dans l'ombre, on croirait voir des fantômes. /Mon uncle avait bien peur. Il passait très vite et sans tourner la tête près des galeries abandonnées, craignant voir apparaître les spectres des victimes des catastrophes passées ». Ver Malva, 1985: 26.

${ }^{34}$ No original: «Vous avez fait preuve non pas de la vaine bravoure des téméraires, mais du courage calme et tranquille du herós" ».
} 
testemunhos destes operários uma espécie de ambivalência, uma relação de amor e de ódio. A passagem do trabalho artesanal para a especialização teria reforçado as dúvidas se esta valorização, forjando um orgulho da profissão, compensaria os sacrifícios. Parece que, junto ao estereótipo de herói, o mal-estar continuava presente. Lazar (1990, p.1085) se perguntava sobre os efeitos da representação comunista de glorificação do operário, considerando que era uma questão difícil de ser verificada. O que seria possível indicar, segundo ele, é a reação de outros segmentos, como a fascinação manifesta pelos intelectuais acerca da vida operária e, especificamente, a dos mineiros.

Parece-me, contudo, que a imagem do heroísmo mineiro, a "grande honra" presente em certa medida no imaginário dos trabalhadores em Minas do Leão (RS) -, consolidou-se não apenas por efeito das ações do Estado, da retórica política e das campanhas publicitárias, mas também pela identificação de gerações de trabalhadores que lhes conferiram o estofo, a alma, para que ela pudesse se colar em gente de carne e osso. Tornou-se inseparável de sua identidade social, gerando, para além dessa imagem pública, um sentimento íntimo, mesmo que permeado por contradições.

Como sugeriu Mattéi (1986: 100-101), a mitologia conduziu os operários a um impasse: eles aprenderam a viver e a se fechar neste universo de imagens valorizadas. Tornava-se difícil ao mineiro fugir desta identidade se não quisesse se marginalizar ou deixar a mina. A meu ver, a "grande honra" assumiu várias faces, ora mais voltada às imagens impactantes mitificando os trabalhadores, ora com contornos de uma "antihonra", enfatizando a força e a coragem do mineiro, mas exibindo também sua vulnerabilidade. As resistências e tentativas de desmistificação desnudavam as contradições entre a heroicidade atribuída e as condições a que eram submetidos. $\mathrm{O}$ anti-heroísmo enfatizava que os mineiros são homens que sentem dor, medo, fadiga e revolta. Parte das biografias e autobiografias revelava que o trabalhador não era nem a figura idealizada da coragem e da abnegação nem um ser embrutecido, podendo retirar de sua indignação e das asperezas do ofício matéria-prima para tecer prosa e poesia.

O engajamento pioneiro de Zola serviu de inspiração a outros escritores, tais como o espanhol Carlos Maria Ydigoras, que se empregou como mineiro de subsolo em Astúrias para escrever o romance Os homens crescem debaixo da terra, de 1961. O enredo é construído em torno da descoberta de um menino de que o corpo de seu pai, morto numa explosão de grisu, não foi recuperado dos escombros, e viria a tornar-se um fantasma das minas, como contavam os velhos mineiros. Alguns desses elementos, como se observou, eram referidos por Malva. Em epígrafe, Ydigoras cita versos seus: 
Lá embaixo, sob a larga noite./ Onde se forjam os homens/ Em quartéis sob a terra./ Onde sopra o grisu e o desmoronamento ameaça./Onde a morte é mais fria.../ Lá embaixo, morada da guerra solitária,/ De homens de carvão e de pulso de uma raça;/ Lá vão entregando à paz seus mortos,/ A morte desafiada,/ Os mortos dos que não contam.../

Lá embaixo, onde crescem os heróis anônimos,/E ocultam sua glória os titãs com alpargatas,/ Lá, onde uma dura raça combate em trevas,/ Lá embaixo, no próprio inferno, irmão... ${ }^{35}$

Nestes versos, estão os principais elementos do imaginário em torno da "grande honra" do mineiro, como a recorrente imagem da "larga noite" para falar da escuridão dos subterrâneos, a da "guerra", do "inferno", da "morte desafiada" e de seus combatentes. Os mineiros são os "heróis anônimos", não reconhecidos, e sua morte é menosprezada socialmente, pois eles "não contam" e a glória de que estão investidos permanece oculta. Eles são considerados resistentes, uma "dura raça", mas ao mesmo tempo são vulneráveis como "titãs com alpargatas". O autor contava que se sentiu tentado a conhecer sua rotina ainda nas minas alemãs do Ruhr, mas foi nos poços nortenhos que se decidiu a trabalhar no subsolo, onde, segundo dizia, foi levado "pela mão" pelos mineiros para percorrer os "reinos subterrâneos". Ex-operário que se tornou escritor, Ydigoras refletia sobre os dois mundos: "Talvez pensem que um homem de letras, mesmo quando já lhe foi familiar o martelo e a chave inglesa, não tem as mãos calejadas..." Mencionava o esforço para tentar traduzir "o modo de ser e de sofrer" dos homens das minas, ressaltando que, com seu testemunho, esperava que se olhasse para a mina, senão com amor, ao menos com respeito. Dedicava a obra aos mineiros, a quem tinha aprendido a admirar pela "heroicidade cotidiana". ${ }^{36}$

\section{Memórias da mina: orgulho, nostalgia e revolta}

A última mina de carvão francesa, La Houve, começou a operar em 1856, em Creutzwald, na Lorena, e foi fechada em 23 de abril de 2004, durante uma cerimônia, segundo a imprensa, «carregada de simbolismo e de tristeza », na qual as autoridades prestaram homenagens aos últimos 410 mineiros, os «gueules noires». Quatro anos

\footnotetext{
${ }^{35}$ Tradução livre do espanhol. No original: Allá abajo, bajo la larga noche./Donde se forjan los hombres/ en cuarteles bajo tierra./ Donde silba el grisu y la quiebra amenaza./ Donde la muerte es más fria.../ Allá abajo, morada de la guerra solitaria,/ de hombres de hulla y del pulso de uma raza; / allá van entregando a la paz sus muertos,/ la muerte desafiada,/ los muertos de los que no contam.../Allá abajo, donde crescen los héroes anônimos,/ y ocultan su glória los titanes con alpargatas/Allá,donde uma dura raza combate en tinieblas.../Allá abajo, en el próprio infierno, hermano... (Ydigoras, 1961)

${ }^{36}$ Ver Ydígoras (1961), Dedicatória.
} 
depois, quando estive na cidade para um trabalho de campo, percebi que ao lado do sentimento de luto que persistia para muitos ex-mineiros notava-se ainda a presença da "grande honra" celebrada e materializada nos objetos que adornam as casas documentos e imagens que reúnem fragmentos de uma memória coletiva (Halbwachs, 1990), guardados como relíquias pessoais. Nas falas dos ex-mineiros, após o desaparecimento da mina, era possível perceber um sentimento de heroicidade frustrada ${ }^{37}$. O fim da mina naquele contexto originou uma reatualização do trabalho de mitificação do trabalhador, através das homenagens públicas e da abertura de museus de carvão. Um antigo mineiro evocava a fala de um colega que saiu da mina no fechamento: “Onde está a minha mina? Sinto falta da mina!”, dizia. Também Graziano, o ex-mineiro italiano referido antes, se comovia ao falar do fim da atividade.

\footnotetext{
Graziano - Eu sempre lamentei o fim da mina. (...) Como dizia outro mineiro quando ainda estávamos na mina: "O métier de mineiro é o mais belo métier do mundo!" Mesmo que isso não seja verdade, mas... [O fim da mina] faz mal ao coração. (...) $\mathrm{O}$ mineiro é assim como um bloco de cimento: a cordialidade, a amabilidade, a sinceridade, a camaradagem não existiam na superfície como existia no subsolo.

- E na superfície?

Graziano - Quando um mineiro está na superfície, isso acaba. A mina não existe senão quando se vai ao subsolo. Lá embaixo, no interior da terra, a 1.100 metros [de profundidade], o mineiro partilhava com os outros mesmo se não os conhecesse, (...) com os italianos, os marroquinos, os russos, os portugueses, os espanhóis, de toda parte. (...) Quando um companheiro não tinha pão dava-se um pedaço mesmo que não o conhecesse.

- É mesmo?

Graziano - Sim, é algo fundamental e que não havia na superfície. ${ }^{38}$
}

Seu relato aporta imagens reveladoras, evocando a "mais bela profissão do mundo", assim como os valores de solidariedade e camaradagem presentes no subsolo, em contraste com a vida na superfície, que eram expressos no ato de partilha do pão com companheiros desconhecidos, pertencentes a diferentes culturas. Essa descrição pungente nos remete ao alcance da interiorização da "grande honra" da profissão naquele meio. Sentimento similar era manifesto por Jacques Urek, um dos seis filhos de um antigo mineiro esloveno. Ex-contramestre da mina, Jacques, que é atualmente uma espécie de historiador local ${ }^{39}$, considerava o fim das minas «um desperdício”, ressaltando que o carvão continua no subsolo e há muitos desempregados. Isso lhe

\footnotetext{
${ }^{37}$ Agradeço a José Sergio Leite Lopes a sugestão da expressão.

${ }^{38}$ Tradução livre do francês.

39 Jacques Urek participou da elaboração de dois livros sobre as minas da região. Um dos livros contém seus desenhos dos modelos arquitetônicos de torres, com uma comparação entre tecnologias adotadas pelas minas da região. Outro trabalho é sobre a presença de cavalos na mina até os anos 1960 .
} 
causava revolta: "Tenho orgulho de ter sido mineiro. Eu alimentei minha família, vivi disso e tenho orgulho disso, mas aqueles que detêm o capital... são uma vergonha, vergonha!" Ele considerava que o trabalho na mina havia lhe conferido dignidade: "Ela deu minha vida, encontrei um caminho!". Em seu relato, percebe-se sinais desta « grande honra » mineira, mais visível entre estes homens que viveram uma militância à esquerda, como no caso de Jacques, ativista da CGT por 18 anos. Ao refletir sobre o ofício, ele dizia que tinha realmente "aprendido a viver" após o ingresso na profissão, assim como fizeram seus cinco irmãos homens, depois da perda do pai, morto pela silicose aos 44 anos. Quando lhe perguntei a razão pela qual um mineiro tinha orgulho do seu ofício, ele mencionou a perda deste sentimento entre as novas gerações:

\footnotetext{
Jacques - Hoje, o orgulho diminuiu um pouco, porque agora todo mundo procura fazer o menos possível e ganhar mais. Nós, era o contrário, ficávamos constrangidos no final da jornada se não podíamos dizer que tivemos um bom rendimento. Ficávamos constrangidos! 40

Bernard [ex-engenheiro da mina, amigo dele, que participa da entrevista] - É o amor pelo trabalho!

Jacques - Isso mesmo! Era assim... oito horas por dia. ${ }^{41}$
}

Outro de meus informantes em Creutzwald, Léon Gauthier, de 77 anos, excontramestre da mina, contava que, mais de uma vez, nos anos 1950, recusou a Ordem do Mérito Nacional, concedida pelo Estado francês quando a mina bateu o recorde de produção. Por fim, foi convencido por seus superiores a aceitá-la, mas impôs como condição a melhora da situação de seus subordinados. Sua resistência à homenagem estava calcada no fato de que a concessão da honraria implicava numa espécie de cooptação por parte dos "grandes chefes". Em posição ambígua para um quadro ${ }^{42}$, ele havia se filiado a um sindicato operário, a Força Operária (FO), preferindo construir uma popularidade entre os trabalhadores que lhe permitia, no entanto, impor forte autoridade como encarregado - estratégia que era destacada por ele como uma espécie de esperteza. ${ }^{43}$ Como Leo, um antigo mineiro entrevistado por mim em Minas do Leão

\footnotetext{
${ }^{40}$ Relato similar me foi dado pelo filho de um antigo mineiro do Norte da França, de origem polonesa. Ele me contou que seu pai e seu tio mantinham disputas sobre quem « era o melhor mineiro », sobre «quem havia produzido mais ». Também ali se podia identificar traços da incorporação da «grande honra ».

${ }^{41}$ Tradução livre do francês.

42 Catherine Roth (2002: 83), considera que nas minas da Lorena havia três categorias hierárquicas: operários, empregados e engenheiros. Gauthier, referido por mim, jogava com seu papel entre os operários e a categoria intermediária, constituindo alternadamente, conforme suas conveniências, formas de «nós » e « eles», para seguir os termos de Hoggart (1973).

43 A própria entidade FO, surgida nos anos 1940, porta suas ambiguidades. Pascal Raggi (s/d), num
} 
(RS), Gauthier lançava mão da comparação com os trabalhadores do mar para falar de sua profissão:

O mineiro é como o marinheiro. (...) O marinheiro vai com seu barco em alto mar e é um ser especial também. Há o marinheiro que morre, que se afoga, há o barco que vira, sempre acontece, sempre acontece. Então, se é um trabalho perigoso? Sabe-se que é um métier perigoso. Pode-se comparar muito bem [com] o ofício do marinheiro (...), o métier do mar e o métier da terra. São duas profissões idênticas do ponto de vista do perigo. ${ }^{44}$

Praticamente até o fechamento da última mina, em 2004, os mineiros franceses continuaram a receber medalhas de "Honra do Trabalho", comemorativas aos 20, 25, 30 e 35 anos de trabalho, mas era necessário que as solicitassem à companhia. Vários exmineiros que entrevistei na Lorena exibiam com orgulho, diante de uma pesquisadora estrangeira, sua coleção de medalhas e de placas honoríficas, caracterizando a "grande honra" da profissão, como no caso do ex-mineiro Roger Stark, militante da CGT e do PCF. Mas nem todos compartilhavam interiormente do significado de tais "honras". Quando perguntei ao ex-mineiro de origem polonesa Stanislas Hewro, de 79 anos, por que os trabalhadores solicitavam essas medalhas, sua resposta desfez as idealizações de uma aspiração honrosa, evidenciando razões práticas: um dia de trabalho pago, uma cerimônia na qual "ouviam um discurso besta e tudo", mas na qual podiam passar quatro horas tranquilamente, bebendo champanhe e fumando. E, à noite, havia a saída com os companheiros para novos festejos. De sua parte, ele não via heroísmo na profissão: "Não é um herói, para mim é um trabalho para ganhar dinheiro. Isso é tudo!" Lembrava que, no começo da carreira, havia a "febre", a paixão pela mina, mas salientava que esta desaparecia após quatro ou cinco anos no subsolo. Quando lhe perguntei se ele havia pensado em mudar de profissão, olhou-me sério e respondeu resoluto: "E fazer o quê?!” A mina era o seu horizonte possível. Já Graziano Balzani, o ex-mineiro italiano, mostrava-se comovido quando assistimos ao vídeo com imagens da cerimônia de entrega de medalhas na qual era um dos homenageados. A condecoração era vista como um evento simbólico que fazia referência ao conjunto de uma vida, imbricando memórias pessoais e coletivas. A nostalgia estava ligada, sobretudo, à relação de camaradagem com os companheiros de jornada.

estudo sobre mineiros de ferro, mencionava que a FO era identificada como defendendo interesses patronais.

${ }^{44}$ Tradução livre do francês. 
Em Creutzwald, o fechamento da última mina deixou uma categoria de congés charbonniers, homens que continuavam a receber $80 \%$ dos salários para ficar em casa à disposição da empresa, até a idade da aposentadoria. Essa condição resultou de um pacto negociado em 1994 entre a Charbonnages de France e os sindicatos CFDT, CFTC e FO (com a oposição da CGT). ${ }^{45} \mathrm{Na}$ época da assinatura do acordo, havia ainda 16 mil mineiros em atividade no país. Se o pacto protegeu os últimos mineiros do desemprego, por outro lado, engendrou efeitos negativos sobre sua dignidade. Como, em sua maioria, estavam proibidos de ter outro emprego, eles se ressentiam da quebra da rotina de trabalho e da ociosidade, que estaria gerando um aumento de depressões, de alcoolismo, de divórcios e até de suicídios, segundo os relatos que ouvi. A permanência dos homens na vida doméstica intensificaria também os conflitos conjugais. Uma parte dos exmineiros buscava trabalho de forma clandestina, no "marché noir", em países como a Bélgica e a Alemanha. As reconversões individuais tomavam formas distintas, mas essas mudanças pareciam sempre operar por relação ao vivido na mina. ${ }^{46}$

Entre a maior parte dos trabalhadores que ouvi na Lorena francesa havia a expressão de um sentimento de desonra desde o fechamento da última mina. Gilbert Pexoto, um dos líderes da CGT e militante do PCF pela terceira geração em sua família, ele próprio um congé charbonnier, expressava assim sua tristeza: “Antes, nós, mineiros, éramos respeitados, admirados pela sociedade, hoje somos vistos como quem recebe sem nada fazer". Esta seria, segundo ele, uma das consequências nefastas do pacto para fechamento das minas que teve a oposição da CGT. Em seu relato, Gilbert manifestava este sentimento de uma heroicidade frustrada ou, em outras palavras, de uma honra ferida da profissão. No caso de La Houve, o que aumentou o luto dos trabalhadores foi o desaparecimento físico da mina, com a demolição dos prédios, das torres, das instalações, e de todos os símbolos exteriores da exploração carbonífera local, apesar dos protestos e das campanhas pela manutenção destes signos de memória coletiva. ${ }^{47}$

Morador em frente à área da antiga mina, Gilbert documentou com fotografias e filmagens, dia após dia, dolorosamente, todos os momentos da implosão das instalações. Pareceu-lhe que o chevalement - a torre que sustentava os cabos do elevador de descida

\footnotetext{
${ }^{45}$ São três medidas: a pré-aposentadoria para os trabalhadores a partir dos 55 anos; a licença mineira para os em final de carreira - congé charbonnier en fin de carrière (CCFC) -, a quem tinha entre 40 e 50 anos na época do fechamento da mina; e a dispensa prévia da atividade - dispense préalable d'activité (DPA) - que se dirige aos mais jovens. Desde 31 de dezembro de 2007, a Charbonnages de France foi extinta. A administração salarial é feita pela Agência Nacional de Gestão dos Direitos dos Mineiros (ANGDM).

${ }^{46}$ A este propósito, ver Cooper-Richet, 2002: 331.

${ }^{47}$ Para que as instalações fossem mantidas, seria necessário que a municipalidade assumisse os encargos, como ocorreu em outras localidades, mas a avaliação foi de que o custo seria demasiado.
} 
ao poço e que, comumente, se destaca na paisagem como o principal símbolo do mundo mineiro - "resistiu" à sua derrubada, sendo necessário o uso de dinamite num dos seus três pontos de apoio. "Parecia que ele não queria cair, como nós", dizia emocionado, enquanto me mostrava as imagens que havia feito com a câmera do celular. Durante o evento oficial de encerramento das atividades da mina, que atraiu a imprensa mundial e milhares de expectadores, Gilbert colocou uma faixa de protesto diante de sua casa, defendendo a continuidade da produção do carvão. Como os outros membros do PCF, o militante não compareceu à cerimônia: ele nada tinha a comemorar. Hoje, à medida que se esvai o reconhecimento à "grande honra", esses trabalhadores buscam refazer o cotidiano por meio de modalidades da "pequena honra", com a atuação em associações culturais e esportivas que, ao lado da política partidária e sindical, ocupam um pouco do vazio deixado pela mina.

Roine Jansson, um artista plástico sueco que conheci durante a temporada na Lorena Francesa, que na juventude havia trabalhado como mineiro de ferro em seu país, passou algum tempo no subsolo acompanhando o trabalho dos últimos mineiros de carvão da mina La Houve, antes do fechamento. Ali ele pintou retratos dos trabalhadores, que foram objetos de uma exposição no Museu da Mina Petite Rousselle, em 2008. O artista, que depois de mineiro tornou-se bombeiro, se emocionava ao contar que, ao se aproximar de um poço de extração na França ou na Bélgica, por exemplo, reconhecia o "cheiro da mina", o mesmo que sentia quando estava na mina de Dannemora, na Suécia. A experiência olfativa o remetia de volta às lembranças das vozes dos antigos companheiros. ${ }^{48}$ Transfigurada pela arte, a aura que distingue a experiência do mineiro perdura também nessas representações sensíveis que preservam traços do mundo vivido por estes trabalhadores.

Naquele contexto, uma face da "grande honra" foi, de fato, imortalizada em museus, lugares em que a fixação da lembrança e a memória dos gestos do cotidiano pode ser também a sua petrificação, onde cenários e instrumentos de trabalho são "museificados", nos termos de Peroni (2001: 256) - autor a quem um informante observou: "Quando se diz museu, se diz fim". ${ }^{49}$ Nos eco-museus e nas minas-museus são os próprios ex-mineiros que se encarregam de imprimir vida a esses espaços, convertidos em guias dos visitantes em galerias reconstituídas ou em antigos prédios,

\footnotetext{
48 Jansson usou em sua exposição um texto com o título: L'odeur de la mine.

${ }^{49}$ Usando a expressão "mina museificada", Cooper-Richet (2002: 334), acentuava que, na criação dos primeiros museus de carvão na França, militantes da CGT, da FO e do PCF posicionaram-se contrários. As minas-museus eram vistas como uma traição: era o toque dos sinos anunciando o fim de uma era.
} 
onde as grandes máquinas jazem inertes, mas onde se busca simular certa autenticidade por relação ao passado. ${ }^{50}$ Como bem observava Lucas (1981), “o fim da mina não é menos encantado do que sua duração".

No museu da mina de Petite-Rousselle, que tive a oportunidade de visitar, juntamente com um grupo de umas vinte pessoas, entrava-se num moderno elevador para descer ao espaço que simula as galerias subterrâneas e onde se encontram os equipamentos mais portentosos que eram usados na extração do carvão. O processo de trabalho ia sendo explicado pelo ex-mineiro Edgar Bastian, de 53 anos, guia voluntário do museu, que se tornou um de meus interlocutores. Ele tinha dificuldades para aceitar o fato de que já não existissem mais mineiros em atividade no país. "Todos os mineiros, em qualquer parte do mundo, são a minha família”, ressaltava. É preciso dizer ainda que a "grande honra" teve lugar privilegiado nas cerimônias que marcaram o fechamento das minas, em encenações teatrais ${ }^{51}$ e na distribuição de lembranças (DVDs, impressos, pequenas amostras de carvão ${ }^{52}$, fotografias, etc.). Nas residências de trabalhadores, ao menos naquelas que pude visitar, para onde se olhasse era possível ver objetos rendendo homenagem à atividade, como as pequenas esculturas de mineiros com seus equipamentos de trabalho em pose destemida e orgulhosa. Em algumas casas, havia fotografias feitas no subsolo, que mostravam rostos encarvoados, com expressões graves, e diplomas de "Honra do Trabalho" enfeitando as paredes das salas de estar. A "grande honra" do mineiro aparecia ainda nas produções literárias e audiovisuais que amplificavam as vozes em torno da mina desaparecida, algumas patrocinadas pela própria companhia, como o livreto ilustrado com fotografias que sugere, de forma paradoxal, uma curiosa e simbólica entrega da mina - que já não existe - aos mineiros, com o título: “.. la mine aux mineurs”. Notava-se a presença da velha aura na gestão dos lugares de memória na qual se mobilizavam atores em disputas em torno dos "autênticos" guardiões desta cultura: eles travavam batalhas simbólicas sobre quem deteria maior autoridade, prestígio ou (re) conhecimento para ser porta-voz dos documentos ou lugares desta memória coletiva. ${ }^{53}$

\footnotetext{
${ }^{50}$ É o caso da maior parte dos museus da mina na França, como de Petite-Rousselle, na Lorena, e também do Museu do Carvão de Arroio dos Ratos, próximo a Minas do Leão (RS).

${ }^{51} \mathrm{O}$ espetáculo Les enfants du charbon, encenado na cerimônia que marcou o fechamento da mina La Houve, teve a participação de dezenas de trabalhadores e de suas famílias.

${ }^{52}$ No fechamento de La Houve, o jornal Le Républicain Lorrain distribuiu 60 mil pedaços de carvão.

${ }^{53}$ Para uma discussão em torno dos "lugares de memória", ver Nora, 1997.
} 


\section{Considerações finais: o valor da honra na contemporaneidade}

Neste artigo, limitei-me a analisar certos modos pelos quais se forjou a imagem de heroísmo dos trabalhadores das minas no universo francês, considerando como pano de fundo uma investigação mais vasta sobre a construção da honra entre trabalhadores de minas de carvão no Brasil e na França. Como se viu, esta imagem estava calcada na dimensão trágica do ofício de mineiro de subsolo, mas foi reforçada pelas políticas de Estado que convocaram os mineiros para aumentar a sua produção atribuindo-lhe um dever patriótico, especialmente durante a Segunda Guerra Mundial - tanto no caso francês como no brasileiro ${ }^{54}$. Algo menos conhecido é como a própria esquerda - do Partido Comunista Francês às centrais sindicais, em especial a CGT - e a própria intelectualidade jogaram um papel essencial no processo de heroicização dos mineiro de subsolo.

Em outras publicações, refleti sobre diversos aspectos que envolvem a construção da honra entre mineiros de carvão, a partir dos dados obtidos nas etnografias realizadas em Minas do Leão (RS) e em Creutzwald, na Lorena Francesa. Minha hipótese mais geral de trabalho é de que uma espécie de "grande honra" foi sendo delineada historicamente, servindo de suporte à imagem de heroísmo que carregam os mineiros de subsolo em diferentes lugares do mundo. Junto à "grande honra", mesclando-se, reforçando-a ou opondo-se a ela, há uma multiplicidade de formas de "pequena honra", alicerçadas na identificação com o métier - a partir do "orgulho" do trabalho bem feito ou das "artes" da malandragem -, em muitos casos na origem rural e, ainda, nos pertencimentos político-sindicais, familiares, religiosos, esportivos, etc. (Cioccari, 2009a, 2009b, 2010a, 2010b, 2011, 2012). No decorrer de minhas pesquisas, considerei que uma ênfase exclusiva no aspecto heroico - ou na "grande honra" - não abarcaria toda a questão, correndo o risco talvez de reforçar essa idealização, daí a observação de outras configurações que emergiam nas narrativas, nas trajetórias individuais e nos pertencimentos coletivos, caracterizando as formas da "pequena honra" presentes no seu cotidiano.

Um primeiro deslocamento teórico para dar conta deste projeto foi desdobrar a noção de honra (no sentido adotado por Pitt-Rivers e Peristiany, 1965, 1992) em duas dimensões: a da "grande honra", mais voltada para as imagens que figuram nas representações do heroísmo mineiro, e a da "pequena honra", correspondendo aos

\footnotetext{
${ }^{54}$ Pretendo explorar o caso brasileiro em análises futuras.
} 
diversos pertencimentos locais e às insurgências nas interações cotidianas, com suas tensões e conflitos internos. Neste sentido, a "grande honra" encontra sua mais clara ilustração no caso dos mineiros franceses, já analisado neste artigo. Como foi dito, ela parte de uma "mitologia" criada em torno do mineiro de subsolo, com sua reverberação íntima mais ou menos entranhada nos sujeitos. Pode-se dizer que a construção do heroísmo, a "grande honra" da profissão, se aproxima, de certo modo, do que Guattari (1986) chamou de perspectiva "molar", enquanto que a "pequena honra", relacionada a diferentes aspectos da vida cotidiana, poderia ser remetida a um caráter "molecular", envolvendo a constante recombinação e reatualização. Os dados etnográficos, assim como parte da bibliografia consultada, levam-me a considerar que, na contemporaneidade, ao invés de uma superação da importância da honra, este valor é atualizado em novos moldes na vida destes trabalhadores tanto no contexto francês como no brasileiro. Ou seja, assiste-se à emergência de novas construções do heroísmo e de novas formas de honra, sempre consideradas em sua multiplicidade.

\section{Referências}

ARIÈS, Philippe. Essais sur l'histoire de la mort en Occident du Moyen Age à nos jours. Paris : Éditions du Seiul, 1975.

BEAUD, Stéphane e PIALOUX, Michel. Retour sur la condition ouvrière. Paris: Fayard, 1999.

BEYNON, Huw. “A Destruição da Classe Operária Inglesa?”. In: Revista Brasileira de Ciências Sociais, v.39, n.2. ANPOCS: São Paulo, 1996. p. 253-279.

. "Protesto ambiental e mudança social no Reino Unido". In: Mana, v.5, n.1. Rio de Janeiro: PPGAS-Museu Nacional/ UFRJ, 1999.

CHARBONNAGES de France. “...La mine aux mineurs...”. In: Service Communication de la Charbonnages de France. Rueil Malmaison: Impression SIRA, Mai 2004, 48 p.

CIOCCARI, Marta. Ecos do subterrâneo: estudo antropológico do cotidiano e memória da comunidade de mineiros de carvão de Minas do Leão (RS). Dissertação (Mestrado em Antropologia Social). Porto Alegre: PPGAS/ UFRGS, 2004.

"Du rire et de la tragédie: notes sur la construction héroïque du métier de mineur de charbon au Brésil et en France". In: Passages de Paris, v. 2008. Paris: APEB-Fr, 2009a. p.1-18.

. "Reflexões de uma antropóloga "andarina" sobre a etnografia numa comunidade de mineiros de carvão". In: Horizontes Antropológicos, v.15, n.32, jul./dez. Porto Alegre: PPGAS/ UFRGS, 2009b. p.217-246.

"Entre o mar e o rochedo: uma análise antropológica sobre as noções

de natureza em Os trabalhadores do mar, de Victor Hugo". In: Cadernos de Campo, n.18. São Paulo: USP, 2010a.

. Do gosto da mina, do jogo e da revolta: um estudo antropológico sobre a construção da honra numa comunidade de mineiros de carvão. Tese de 
doutorado em Antropologia Social. Rio de Janeiro: PPGAS, Museu Nacional/ UFRJ, $2010 b$.

"Risco, riso e respeito; notas sobre a construção da honra entre os trabalhadores nas minas de carvão no Brasil e na França". In: Revista Brasileira de História e Ciências Sociais, v.3. São Leopoldo: Unisinos, 2011. p.17 - 27.

"Aspectos da construção da honra entre mineiros de carvão em uma comunidade no sul do Brasil". In: Revista Theomai, v. 24. Buenos Aires: UNQ, 2012. p. 141-165.

CLYNE, Rick J. Coal people: life in southern Colorado's Company Towns, 1890-1930. Denver: The Colorado Historical Society, 1999.

COOPER-RICHET, Diana. Le peuple de la nuit: mineurs et mines en France, XIX et XX siècles. Paris: Perrin, 2002.

DESBOIS, Évelyne, JEANNEAU, Yves \& MATTÉI, Bruno. La fois des charbonniers: les mineurs dans la Bataille du charbon 1945-1947. Paris: FMSH, 1986.

DUARTE, Luiz Fernando Dias. "Identidade social e padrões de agressividade verbal em um grupo de trabalhadores urbanos". In: LEITE LOPES, J. S. (org.). Cultura $e$ identidade operária. Rio de Janeiro: Marco Zero, 1987.

ECKERT, Cornelia. Os homens da mina: um estudo das condições de vida $e$ representações dos mineiros de carvão em Charqueadas/RS. Dissertação de Mestrado em Antropologia Social. Porto Alegre: PPGAS/ UFRGS, 1985. Une ville autrefois minière: La Grand-Combe, étude d'Anthropologie

Sociale. Thèse (Doctorat en Anthropologie Sociale). Paris: Université Paris V, Sorbonne/ Sciences Humaines, 1991.

"Memória e identidade. Ritmos e ressonâncias da duração de uma comunidade de trabalho: mineiros de carvão (La Grand-Combe, França)". In: Cadernos de Antropologia, n.11. Porto Alegre: UFRGS, 1993.

GROSSI, Yone. Mina de Morro Velho: a extração do homem. Rio de Janeiro: Paz e Terra, 1981.

GUATTARI, Félix. Les d'hiver: 1980-1985. Paris: Bernard Barrault, 1986.

HALBWACHS, Maurice. A Memória coletiva. São Paulo: Vértice, 1990.

HUGO, Victor. Os trabalhadores do mar [1866]. São Paulo: Editora Nova Cultural, 2003.

INSTITUT d'Histoire Social Minière. Mineurs immigrés: histoire, témoignages XIXe, XXe siècles. Montreuil: VO Éditions, 2000.

KASSAPI, Athena. "L'art de travailler au fond de la mine. Enquête à Kassandra em Grèce du Nord". In: Revue Ethnologie Française, v.31, n.3. Nanterre: PUF, 2001. p. 423-430.

LANCIEN, Didier. "Note crítique: Les mineurs de Grande-Bretagne au XIXe et au XXe Siécle". In: Annales. Économies, Sociétés, Civilisations. 36 Année, n.6, nov-déc, 1981. Paris: Armand Colin, CNRS et de l'École Des Hautes Études en Sciences Sociales, 1981. p. 1111-1136.

LAZAR, Marc. "Le mineur de fond: um exemple de l'identité du PCF". In: Revue française de science politique, v. 35, n.2. Paris: Fondation Nationale des Sciences Politiques et l'Association Française de Science Politique, 1985. p.190-205.

"Damné de la terre et homme de marbre. L'ouvrier dans l'imaginaire du PCF du milieu des années trente à la fin des années cinquante". In: Annales. Économies, Societés, Civilisations. $45^{\circ}$ Année, n.5, sep-ouc, 1990. Paris: Armand Colin, CNRS et de l'École Des Hautes Études en Sciences Sociales, 1990. p. 1071-1096.

LEITE LOPES, José Sérgio. O vapor do diabo: o trabalho dos operários de açúcar. Rio de Janeiro: Paz e Terra, 1978. 
LEITE LOPES, José Sérgio. Cultura e identidade operária: aspectos da cultura da classe trabalhadora. Rio de Janeiro: Editora Marco Zero, 1987.

LEITE LOPES, José Sérgio. A tecelagem dos conflitos de classe na cidade das chaminés. São Paulo/Brasília: Ed. Marco Zero e Ed. Universidade de Brasília, 1988.

LEITE LOPES, José Sergio; ALVIM, Rosilene. "Uma autobiografia operária: a memória entre a entrevista e o romance". In: Estudos Avançados, v. 13, n.37, set./dez. São Paulo: Instituto de Estudos Avançados da Universidade de São Paulo, 1999. p. 105124.

L' ESTOILE, Benoît de. "Le goût du passé". In: Terrain, n.37. Paris: Ministère de la Culture, 2001.

LUCAS, Philippe. La religion de la vie cotidienne. Paris: PUF, 1981.

MALVA, Constant. Ma nuit au jour le jour. Paris: Ed. Maspero, 1978.

La nuit dans les yeux. Bruxelles/ Paris: Éditions Labor/Fernand

Nathan, 1985.

MICHEL, Joël. La mine dévoreuse d'hommes. Paris: Gallimard, 1993.

MINAYO, Maria Cecília dos Santos. Os homens de ferro: estudo sobre os trabalhadores da Vale do Rio Doce em Itabira. Rio de Janeiro: Dois Pontos, 1986.

MOORE JR., Barrington. "Militância e apatia no Ruhr antes de 1914". In: Injustiça: as bases da obediência e da revolta. São Paulo: Brasiliense, 1987.

NASH, June. We eat the mines and the mines eat us: dependency and exploitation in Bolivian tin mines. New York: Columbia University Press, 1979.

Comemos a las minas y las minas nos comem nosotros: dependencia y explotación en las minas de estaño bolivianas. Buenos Aires: Antropofagia, 2008.

NASH, June \& ROJAS, Juan. He agotado mi vida en la mina: Autobiografía de un minero boliviano. Buenos Aires: Nueva Visión, 1976.

NAVEL, Georges. Travaux. Paris: Gallimard, 2004.

NEZOSI, Gilles. "Compte rendu de Pascal Raggi, Les mineurs de fer au travail, 2007". In: Le Mouvement Social, n. 226, 8 avril 2008. Paris: Éditions de la Découverte, 2008. En ligne: http://mouvement-social.univ-paris1.fr/document.php?id=1164. Acesso em $12 / 08 / 2009$.

NOIRIEL, Gérard. "L'histoire de l'immigration: note sur un enjeu". In: Actes de la recherche en sciences sociales, v.54, septembre, 1984. Paris: Editions du Seuil, 1984. p. $72-76$.

Éditions du Seuil, 1986 (ed. 2002).

Les ouvriers dans la societé française, XIXe et Xxe siècle: Paris:

NORA, Pierre (org.). Les lieux de mémoire. v.1. Paris: Gallimard, 1997.

PERISTIANY, John; PITT-RIVERS, Julian (orgs.). Honor y gracia. Madrid: Alianza Editorial, 1992.

PERONI, Michel. "Ce qui reste de la mine dans la région stéphanoise: la mine faite objet, la mine faite sujet". In : BENSA, A. \& FABRE, D. (dir.). Une histoire à soi. Paris: Éditions de la Maison des Sciences de l'Homme, 2001.

PITT-RIVERS, Julian. "Honra e posição social”. In: PERISTIANY, J. G. (org.). Honra e vergonha: valores das sociedades mediterrâneas. Lisboa: Fundação Calouste Gulbenkian, 1965. p. 13-59.

PITT-RIVERS, Julian. "Friendship and Authority". In:

Sierra. London: The University of Chicago Press, 1971. p.137-160.

The People of the . Anthropologie de l'honneur: La mésaventure de Sichem. Paris: Le

Sycomore, 1983.

"A doença da honra". In: GAUTHERON, M. (org.). A honra: imagem de si ou dom de si: um ideal equívoco. Porto Alegre: LP\&M, 1992. 
POITOU, Jean-Claude. Nous les mineurs: 1883-1983. Paris: Federation Nationale des Travailleurs du sous-sol CGT, Alsacienne d'Impression, 1983.

PONTY, Janine. Les polonais du Nord ou la mémoire des corons. Paris: Éditions Autrement, 1995.

Les polonais en France. Paris: Èditions du Rocher, 2008.

RAGGI, Pascal. L'action syndicale de la Féderation Régionale CGT des Mineurs de Fer de Lorraine (1950-1967). Disponível: http://www.ihs.cgt.fr/pdf_pascal_RAGGI.pdf. Acesso em 12/08/2009.

REDFIELD, Robert. "The social organization of tradition". In: POTTER, J.M. et al.(orgs). Peasant society: a reader. Berkeley: University of California, 1967. p.25-34.

ROTH, Catherine. "24 heures sur 24 heures à la mine, porion et ingénieur: le travail comme art de vivre". In: Terrain, n. 39. Paris: Ministère de la Culture, 2002.

SCHWARTZ, Olivier. Le monde privé des ouvriers: hommes et femmes du Nord. Paris: PUF, 1990.

SILVA, Cristina Ennes da. Nas profundezas da terra: um estudo sobre a região carbonífera do Rio Grande do Sul (1883/1945). Tese (Doutorado em História). Porto Alegre: PUCRS, 2007.

SIMONIN, Louis. La vie souterraine: les mines et les mineurs [1867]. Paris: Champ Vallon, 1981.

TREMPÉ, Rolande. Les trois batailles du charbon. Paris: La Découverte, 1989.

Ouvrières, 1971. . Les mineurs de Carmaux 1848-1914. Tome I e II. Paris: Les Éditions

"Réflexions préliminaires sur la notion d'étranger; le recrutement minier, les conséquences de la crise de 1929, les poids des guerres". In: Mineurs immigrés. Histoire, témoignages XIXe, Xxe siècles. Institut d'Histoire Sociale Minière. Paris: VO Éditions, 2000. p. 12-24.

VISEUX, Augustin. Mineur de fond. Paris: Plon, 1991.

VOLPATO, Terezinha Gascho. A pirita humana: os mineiros de Criciúma. Dissertação de Mestrado. Florianópolis: UFSC, 1982.

YDÍGORAS, Carlos Maria. Os homens crescem debaixo da terra. Lisboa: Ed. Bertrand, 1961.

ZOLA, Émile. Carnets d'enquêtes. Une ethnographie inédite de la France. Présentation de Henri Mitterrand. Paris: Plon, 1987.

. Germinal [1885]. São Paulo: Abril Cultural, 1979.

Jornais e periódicos:

C'était La Houve. Le Républicain Lorrain, Metz, mai 2004. Spécial charbon.

Forbach: l'épopée de la mine. Le Républicain Lorrain, Metz, 27 novembre 1997. Supplément du Jeudi.

JEAN LOUIS, Robert. Les trois batailles des mineurs du Nord. Le Monde, Paris, p.9, 19 déc. 2000.

1963: Quand de Gaulle a plié. Le Républicain Lorrain, Metz. Supplément du 22 avril 2004, p.13.

Le Travailleur du sous-sol, bimestriel édité par la Branche Mines de la FNME-CGT, n. 906, Montreuil, novembre-décembre 2005.

La Houve tourne la page. Le Républicain Lorrain, Metz. Supplément du 22 avril 2004.

RÚSSIA: Heroes of Labor. Time, Monday, 16 dec. 1935, capa, p.26-27. Disponível: http://www.time.com/time/magazine/0,9263,7601351216,00.html, Acesso 31/07/2009. 
Une étudiente brésilienne enquête sur les mines. Le Républicain Lorrain, Metz, 07 jul. 2008.

Filmes, Vídeos e DVDs:

Fermeture du siège La Houve, Charbonnages de France, 2004. (DVD)

La mort du travailleur, documentário dirigido por Michael Glawogger, Alemanha, 2005, 119mn.

Poste du matin à la Houve, Charbonnages de France, réalisation 2Jmédia, Aix-enProvence, 2006. (DVD)

Remise de médailles aux mineurs, 1991, Puits Merlebach-Forbach. (Video)

Recebido em: 23/03/2012

Aprovado em: 31/05/2012 